\title{
LOCATION, LOCATION, LOCATION: HOW THE ACCA'S Categorical Approach Produces Vast Sentencing DisCREPANCIES, AND WHY THE SENTENCING GUIDELINES SHOULD REPLACE IT
}

\author{
HALEY E. ROACH*
}

\section{INTRODUCTION}

John has lived his entire life in Gary, Indiana. He joined a gang when he was fourteen and has been in and out of the correctional system ever since. At nineteen, he and two other gang members set out to break into a local drug store. They figured it would be less risky to do it after the drug store had closed, so they waited until around two o'clock in the morning and made sure to watch the manager leave before they made their move. They pried the sliding door open with a crow bar and hopped the counter, busted open the register and grabbed as much cash as they could as the alarm shrieked. Within two minutes of entering, they were headed back out the now-busted door and running back toward their car, which was parked three blocks away. But the police were quick to respond, and intercepted them, cash in hand. The State convicted John of burglary of a building or structure, a Level 4 felony under Indiana Code $\S 35-43-2-1$, for which John was sentenced to two years in state prison. ${ }^{1}$

After getting out of prison, John continued activities with the gang, and committed several more drug store burglaries over the course of the next eight years, for two of which he was charged and pleaded guilty. John, now twentynine-years-old, has a lengthy criminal record. He is pulled over for a speeding ticket on Interstate 90 in Gary, Indiana. The officer approaches the vehicle and notices a 9-millimeter handgun lying on the floor of the car on the front passenger side. John is arrested and, due to his criminal record, is prosecuted and convicted in federal court for being a felon in possession of a firearm under 18 U.S.C. $\S$ 922(g). ${ }^{2}$ The federal prosecutor also charges John under the Armed Career Criminals Act of 1984 ("ACCA"), a federal law requiring minimum sentences of fifteen years in prison if the court finds that the defendant has three or more "violent felonies." Because John's burglaries were in Indiana, where burglary qualifies as a "violent felony" under the ACCA, John is sentenced under the ACCA to fifteen years in federal prison for possession of a firearm. ${ }^{4}$ But the ACCA does not produce the same result in Chicago, just fifteen miles away from where John lives.

Paul lives in Chicago and has lived the same exact life as John. Paul joined a gang as a young teenager and is not new to the criminal justice system. Like

* J.D. Candidate, May 2019, Indiana University Robert H. McKinney School of Law; B.A., May 2016, University of Dayton-Dayton, Ohio.

1. IND. CoDE $\S 35-43-2-1(1)$ (2018).

2. 18 U.S.C. $\S 922(\mathrm{~g})(2018)$.

3. Id. $\S 924(\mathrm{e})(1)$.

4. Id. $\S 924(\mathrm{e})(2)(\mathrm{B})$. 
John, he participated in a series of drug store burglaries, two of which resulted in guilty pleas. A police officer pulls Paul over for speeding on a different segment of Interstate 90, in Illinois, and notices a 9-millimeter handgun lying on the floor on the passenger side. Like John, due to Paul's criminal history, Paul is prosecuted in the federal system for being a felon in possession of a firearm under 18 U.S.C. $\S 922(\mathrm{~g}) .^{5}$ But the prosecutor in Paul's case cannot apply the ACCA because Illinois, unlike Indiana, defines burglary in a way that does not qualify under the ACCA.

Indiana defines burglary as "break[ing] and enter[ing] the building or structure of another person, with intent to commit a felony or theft." " Illinois, on the other hand, defines burglary as "without authority. . . knowingly enter[ing] or without authority remain[ing] within a building, housetrailer, watercraft, aircraft, motor vehicle, railroad car, or any part thereof, with intent to commit therein a felony or theft." "Federal courts decided that the ACCA covers Indiana's definition, but found the ACCA's "violent felony" definition did not cover the Illinois statute. If the federal prosecutor still seeks to charge Paul with a federal crime, Paul will likely receive a sentence of about two-and-a-half years for the possession charge, even though his criminal history is identical to John's record. ${ }^{8}$ Identical crimes, identical circumstances, identical statute, identical circuit, but resulting in huge sentencing discrepancies.

The ACCA requires a federal judge to sentence a defendant with three or more convictions of "violent felonies" to at least fifteen years in prison for unlawful possession of a firearm. ${ }^{9}$ Measures like the ACCA are "three strikes" laws, meaning that three or more convictions on a defendant's criminal record yield harsher sentences. ${ }^{10}$ Many states adopted three strikes laws in the twentieth century. ${ }^{11}$ State and federal courts generally upheld these sentencing policies as constitutional. $^{12}$ But the ACCA is different-it is a federal law passed by Congress to apply to "armed career criminals" committing "violent felonies" from all jurisdictions, requiring federal sentencing courts to determine which defendants qualify as "armed career criminals" based upon criminal records full of state crimes. ${ }^{13}$ Although individual states utilized the three-strikes sentencing scheme for decades, the ACCA is different in that, as part of the federal criminal code, the ACCA forces federal courts to interpret statutes across jurisdictions,

5. Id. $\S 922(\mathrm{~g})$.

6. IND. CODE $§ 35-43-2-1(1)$.

7. 720 ILl. COMP. STAT. 5/19-1(a) (2018).

8. See U.S. Sentencing Guidelines Manual ch. 5, pt. A (U.S. Sentencing Comm'N 2016).

9. 18 U.S.C. $\S 924(\mathrm{e})(1)$.

10. See generallyid. § 924 .

11. Michael Vitiello, Three Strikes Laws: A Real or Imagined Deterrent to Crime, 29 Hum. RTS. 3, 3-4 (2002).

12. Id. at 5 .

13. H.R. ReP. No. 98-1073, at 1 (1984) (Conf. Rep.). See generally 18 U.S.C. § 924. 
which is inefficient and produces unfair results. ${ }^{14}$

This Note will explain the origins of the ACCA, the unfair results that the ACCA produces, and the constitutional pitfalls accompanying the ACCA's provisions. This Note will also present a more efficient and elegant method to punish career criminals. Congress passed the ACCA to combat record crime rates across the country in the late 1970s and early 1980s. ${ }^{15}$ While record crime rates and struggling state criminal justice systems may have warranted the passing of the ACCA, courts diluted its effectiveness and purpose in Taylor v. United States. ${ }^{16}$ The ACCA is also vulnerable to damning constitutional challenges by defendants, demonstrated in 2015 in Johnson v. United States. ${ }^{17}$ While the ACCA was warranted to address unprecedented crime rates when it was passed in 1984, it is no longer the most efficient way to address recidivist criminals. The Federal Sentencing Guidelines accomplish the same goals as the ACCA, without the inefficient legal analysis that accompanies an enhanced sentence under the ACCA. The Guidelines use criminal history to increase potential sentencing ranges, with more flexibility for sentencing judges and attorneys and fewer potential constitutional challenges. ${ }^{18}$ This Note will argue that the ACCA and its sentencing enhancement provisions should be repealed, in favor of utilizing the Federal Sentencing Guidelines that are already in place to address recidivist criminals.

\section{AN ANSWER TO THE CRIME CRISIS: HOW THE ACCA CAME TO BE}

\section{A. Why the Public Called for a Solution}

The crime wave America experienced in the 1970s and 1980s set records that still stand today. ${ }^{19}$ Overall, crime has dropped from $13,408,300$ in 1980 to

14. See generally United States v. Perry, 862 F.3d 620 (7th Cir. 2017); United States v. Reyes-Ochoa, 861 F.3d 582 (5th Cir. 2017); United States v. Lobaton-Andrade, 861 F.3d 538 (5th Cir. 2017); United States v. Phillips, 853 F.3d 432 (8th Cir. 2017); United States v. Quarles, 850 F.3d 836 (6th Cir. 2017); United States v. Lamb, 847 F. 3d 928 (8th Cir. 2017); United States v. Nicholas, No. 16-3043, 686 F. App'x 570 (10th Cir. 2017); United States v. Taylor, 843 F.3d 1215 (10th Cir. 2016); United States v. Doctor, 842 F.3d 306 (4th Cir. 2016); United States v. Haney, 840 F.3d 472 (7th Cir. 2016); United States v. Ritchey, 840 F.3d 310 (6th Cir. 2016); United States v. White, 836 F.3d 437 (4th Cir. 2016).

15. See generally H.R. REP. No. 98-1073, at 1 (Conf. Rep.).

16. See generally Taylor v. United States, 495 U.S. 575 (1990).

17. See generally Johnson v. United States, 135 S. Ct. 2551 (2015).

18. See discussion infra Part III.A.

19. Uniform Crime Reporting Statistics, U.S. DEP'T JuST., https://www.ucrdatatool.gov/ Search/Crime/State/OneYearofData.cfm (select "United States-Total" under "Choose one or more states" menu; then select both "Number of violent crimes" and "Number of property crimes" from "Choose one or more variable groups" menu; then select relevant year from "Choose one year" menu; then follow "Get Table" hyperlink). 
9,202,093 in 2016. ${ }^{20}$ Though President Trump was quick to call attention to the modern crime "epidemic" in Chicago, ${ }^{21}$ elevated violent crime in urban centers seems to be isolated to Chicago. ${ }^{22}$ New York, Los Angeles, and Houston all declined at a uniform rate with Chicago until 2012-2013, when Chicago crime rates spiked. ${ }^{23}$ All other major cities have remained well below 1980s levels, in part due to legislative efforts to target the criminals viewed as responsible for this epidemic. $^{24}$

The latter half of the 20th century saw an unprecedented increase in crime across the country. ${ }^{25}$ In 1960, the total number of crimes committed was $3,384,200{ }^{26}$ In 1979, two years before the first draft of the ACCA was introduced, the total number of crimes exceeded $12,249,500 .{ }^{27}$ Of the $12,249,530$ crimes, only 32,688 criminal cases were commenced in federal courts during the same year. ${ }^{28}$ The remaining millions were left to state courts to process, overwhelming local courts and law enforcement, bringing the vast majority of criminal cases to a glacial pace, and overcrowding state prisons at a time when the increasing crime rate did not seem to be slowing down. ${ }^{29}$

The prevalence of crime in 1980s America was a prominent issue in every state, local, and federal election campaign, and could not be ignored. ${ }^{30}$ Calls to Congress for a solution became deafening-from the media, public, and government officials. ${ }^{31}$ An emergency room doctor called the routine carnage at

20. Id. Overall crime includes violent offenses, property offenses, and drug and weapons possession offenses. Id.

21. Kori Rumore, When Trump Talks about Chicago, We Track it: 'The Crime Spree is a Terrible Blighti, ' CHI. TRIB. (Dec. 15, 2017), http:/www.chicagotribune.com/news/local/breaking/ ct-trump-tweets-quotes-chicago-htmlstory.html [https://perma.cc/EC4X-3ATL].

22. Ann Givens, Chicago's Murder Rate is Typical for a Major Metropolis-Until Fatal Shootings Are Factored In, TRACE (Jan. 4, 2016), https://www.thetrace.org/2017/01/chicagomurder-rate-fatal-shootings/ [https://perma.cc/L3JT-3L7T].

23. Id.

24. $I d$.

25. Uniform Crime Reporting Statistics, supra note 19.

26. $I d$.

27. Id.

28. Caseloads: Criminal Cases, 1870-2016, FED. Jud. CTR., https://www.fjc.gov/history/ courts/caseloads-criminal-cases-1870-2016 [https://perma.cc/494M-D987]. It is true, of course, that the prosecution of crimes committed in 1979 might not have commenced in 1979. But it is also true that some criminal cases commenced in 1979 prosecuted crimes committed prior to 1979.

29. Brent E. Newton \& Dawinder S. Sidhu, The History of the Original United States Sentencing Commission, 1985-1987, 45 Hofstra L. Rev. 1167, 1182, 1223 (2017).

30. See October 28, 1980 Debate Transcript, Commission on Presidential Debates (2015), http://www.debates.org/index.php?page=october-28-1980-debate-transcript [https://perma.cc/87AN-FVNA].

31. Richard J. Meislin, The Crime-Without-Punishment Crisis; News Analysis, N.Y. TIMES (Aug. 10, 1981), http://www.nytimes.com/1981/08/10/nyregion/the-crime-without-punishmentcrisis-news-analysis.html [https://perma.cc/PB87-DRYY]. 
the hands of drug cartels and street gangs in Miami as nothing less than "war." 32 James Wilson, a writer for The Atlantic, lost faith in institutional deterrence efforts altogether, claiming more subtle strategies like police-community interaction would reduce crime in a specific area. ${ }^{33}$ Then-Chief Justice Warren Burger spoke to the American Bar Association, stressing the incredible importance of addressing crime, "defense against crime was as vital to national security as "the budget of the Pentagon." ${ }^{34}$ President Reagan lent his opinion to what he deemed a "crisis," admitting to the International Association of Chiefs of Police, "There has been a breakdown in the criminal justice system in America." 35

Commentators disagree on what exactly caused the steep climb in crime rates in the 1970s and 1980s. Some blame economic forces, pointing to "economic stagnation" following "industrial decline" in blue collar cities. ${ }^{36}$ Others point to citizens' perception of military action as justification for lashing out against the government and conventional society. ${ }^{37}$ Kevin Nevin, a consultant for the Department of Housing and Urban Development, blamed atmospheric lead levels, asserting that "moderately high levels of lead exposure are associated with aggressivity, impulsivity, ADHD, and lower IQ," which could have contributed to a predisposition for risk-taking behaviors and criminal tendencies. ${ }^{38}$

Additionally, crime took on a different infrastructure with the explosion of the drug trade from Central and South America. ${ }^{39}$ American criminal organizations had cultivated Mexican marijuana markets since the forties, but the rise of Columbian cocaine and the Medellin cartel triggered the U.S. government

32. Art Harris, In Miami, Puerto Rican Mayor Faces Politically Macho Cubans, WASH. Post (Oct. 25, 1981), https:/www.washingtonpost.com/archive/politics/1981/10/25/in-miami-puertorican-mayor-faces-politically-macho-cubans/ebe 1010 c-0 c 5d-486f-9fa 4 a7c80fb1390c/?utm_term=.1a6a81ff662b [https://perma.cc/SF5A-ZXQV].

33. James Q. Wilson, Thinking About Crime: The Debate Over Deterrence, ATLANTIC (Sept. 1983), https://www.theatlantic.com/past/docs/politics/crime/wilson.htm [http://perma.cc/SB8VCGN3].

34. Tom Wicker, Dramatizing the Debate on Crime, IndiAnAPOLIS STAR, Feb. 12, 1981, at 27.

35. S. REP. No. 97-585, at 27, 43 (1982) (Conf. Rep.).

36. Christina Sterbenz, New York City Used to Be a Terrifying Place, Bus. InSIDER (July 12, 2013), http://www.businessinsider.com/new-york-city-used-to-be-a-terrifying-place-photos-2013-7 [https://perma.cc/PY98-B9QX].

37. Charles C. Bebber, Increases in U.S. Violent Crime During the 1980s Following Four American Military Actions, 9 J. InTERPERSONAL ViOLENCE 109 (1994).

38. Kevin Nevin, Lead: America's Real Criminal Element, Mother Jones (Feb. 11, 2016), https://www.motherjones.com/environment/2016/02/lead-exposure-gasoline-crime-increasechildren-health/ [https://perma.cc/DN92-JUXA].

39. Steven Hyland, The Shifting Terrain of Latin American Drug Trafficking, ORIGINS: Current Events In Hist. PersP. (Sept. 2011), http:/origins.osu.edu/article/shifting-terrain-latinamerican-drug-trafficking/page/0/1 [https://perma.cc/85EY-XWNV]. 
to declare a "War on Drugs" in $1971 .{ }^{40}$ With networks already established from decades of marijuana smuggling and dealing, the "War on Drugs" could not prevent the Columbian cartels from controlling seventy percent of the illicit drugs trade by 1981 , generating nearly 1.5 billion dollars annually. ${ }^{41}$

As cartels' power, profits, and production increased, so too did poverty and violent crime across the country. ${ }^{42}$ Several studies linked drug use-specifically heroin and crack cocaine - to violent crime, "typically committed over drug possession and sale," as well as property crime - presumably to acquire a way to purchase more drugs to fuel the habit. ${ }^{43}$ In order to combat prodigious crime, Congress passed prodigious anti-crime legislation. ${ }^{44}$

\section{B. How the Federal Government Answered}

With all Americans, including the President, expecting Congress to take legislative action to stop, or at least slow, the decades-long rise in crime, Senator Arlen Specter introduced the first version of the Armed Career Criminals Act in $1981 .{ }^{45}$ Senator Specter praised the steps toward legislation, saying, "[t]he beauty of this proposal is that it provides for a national response to a national crisis. ${ }^{\circ 6}$ Specter added that " $[\mathrm{t}]$ he time has come to translate public outrage and private fear into a national response to rampant crime rates." ${ }^{47}$ After three years of a back-and-forth between the House of Representatives, the Senate, and President Reagan, the ACCA was first signed into law in $1984 .{ }^{48}$

The ACCA embodied a new federal strategy to support local law enforcement, employing federal prosecution resources to alleviate states' struggles. ${ }^{49}$ Prior to the ACCA, federal jurisdiction over criminal offenses was much narrower and limited to bank robberies, interstate smuggling and RICO cases, and certain drug-related offenses. ${ }^{50}$ The ACCA introduced dozens of federal firearm offenses, including unlawful manufacture, sale, receipt, use, and

40. $I d$.

41. Id.

42. Helene Raskin White \& D.M. Gorman, Dynamics of the Drug-Crime Relationship, 2000 CRim. Just. (NATURE OF CRIME) 151, 153.

43. Id. at 153 .

44. See discussion infra Section I.B.

45. S. ReP. No. 97-585, at 5 (1982) (Conf. Rep.).

46. Armed Career Criminal Act of 1984: Hearing on H.R. 1627 and S. 52 Before the H. Comm. on the Judiciary, 98th Cong. 21, 27 (1984) (statement of Sen. Arlen Specter) [hereinafter Armed Career Criminal Act of 1984 Hearing].

47. Id. at 29 .

48. Id. at 24-25; Armed Career Criminal Act of 1984, Pub. L. No. 98-473, § 1801, 98 Stat. 1837 (1984).

49. Armed Career Criminal Act of 1984 Hearing, supra note 46, at 4-5.

50. Sara Sun Beale, Federalizing Crime: Assessing the Impact on the Federal Courts, 543 Annals Am. ACAD. Pol. \& Soc. Sci. 39, 41-43 (1996). 
possession. ${ }^{51}$ Rather than replace similar state firearms offenses, federal criminal legislation like the ACCA "supplement[s] state law rather than nullifying or displacing it." ${ }^{, 52}$

Congress' new strategy targeted what it deemed a "career criminal"- those individuals making a livelihood via property crimes and theft, the individuals responsible for the majority of crime in urban areas. ${ }^{53}$ As Senator Arlen Specter explained to the Subcommittee on Crime of the House of Representatives Judiciary Committee, "[t]he key to the Armed Career Criminal Act is the revelation that a surprisingly small number of criminals commit the vast majority of crimes. .. . [S]ix percent of the criminals arrested commit as much as $70 \%$ of the serious crime[s]. ${ }^{954}$ Congressional reports cited to several statistics justifying the concentration of federal resources on "robberies, burglaries, and drugs."

To ensure these career criminals received more severe sentences than they would have otherwise received under state law, the ACCA included mandatory minimum sentences for those defendants with criminal histories of certain offenses:

(e)(1) In the case of a person who violates section $922(\mathrm{~g})$ of this title ... and has three previous convictions by any court referred to in section $922(\mathrm{~g})(1)$ of this title ... for a violent felony or a serious drug offense, or both, committed on occasions different from one another, such person shall be fined under this title and imprisoned not less than fifteen years, and, notwithstanding any other provision of law, the court shall not suspend the sentence of, or grant a probationary sentence to, such person ${ }^{56}$

As the above provision states, individuals charged with a firearms offense under $\S 922(\mathrm{~g})$, with three or more previous convictions of "violent felonies," are subject to the mandatory sentence of at least fifteen years. ${ }^{57}$ Considering Senator Specter's statements on property crimes and drug use, the ACCA targets exactly those types of offenses in its definition of "violent felonies"- the offenses that qualify defendants for the enhanced sentence. ${ }^{58}$ The definition for "violent felonies" under the ACCA is below:

(B) the term "violent felony" means any crime punishable by imprisonment for a term exceeding one year, or any act of juvenile delinquency involving the use or carrying of a firearm, knife, or

51. See 18 U.S.C. $\$ 922$ (2017).

52. Beale, supra note 50, at 44 .

53. Armed Career Criminal Act of 1984 Hearing, supra note 46, at 17.

54. Id.

55. Id. at 17-18.

56. 18 U.S.C. $\S 924(\mathrm{e})(1)$. Section 922(g), referenced by $\S 924(\mathrm{e})(1)$, outlines the various firearms offenses of the ACCA and is discussed supra text accompanying notes 51-55.

57. $\S 924$.

58. $\S 924(\mathrm{e})(2)(\mathrm{B})$. 
destructive device that would be punishable by imprisonment for such term if committed by an adult, that-

(I) has an element the use, attempted use, or threatened use of physical force against the person of another; or

(ii) is burglary, arson, extortion, involves use of explosives, or otherwise involves conduct that presents a serious potential risk of physical injury to another. ${ }^{59}$

The section above is split into three different definitions. ${ }^{60}$ The first, subsection (i) above, is the "force clause." ${ }^{61}$ The second definition, the first clause of subsection (ii) above, contains the enumerated offenses: burglary, arson, extortion, and use of explosives. ${ }^{62}$ The third and final definition, the second clause of subsection (ii) above, is the residual clause. ${ }^{63}$ To determine whether a previous conviction applies, and in turn whether a defendant is subject to the mandatory fifteen-year sentence, the prosecutor must show that the convicting state statute(s) for the previous convictions: (1) includes one of the elements of the "force clause;" (2) is one of the enumerated offenses; or (3) "involves conduct that presents a serious potential risk of physical injury to another." ${ }^{64}$ This process of examining the convicting statute is known as the "categorical approach," 65 implemented by the Supreme Court in the first landmark case to consider the constitutional ramifications of the ACCA. ${ }^{66}$

\section{HOW TAYLOR ALTERED THE COURSE}

\section{A. The Ruling}

Arthur Taylor pleaded guilty to one count of possession of a firearm by a convicted felon under 18 U.S.C. $§ 922(\mathrm{~g}){ }^{67}$ Taylor had three previous felony convictions for burglary in the second degree in Missouri, so the prosecutor argued that the fifteen-year mandatory minimum applied. ${ }^{68}$ The district court agreed that Taylor was an armed career criminal with three or more convictions of "violent felonies," and sentenced Taylor to fifteen years in prison. ${ }^{69}$

59. Id.

60. Id.

61. United States v. Starks, 861 F.3d 306, 314 (1st Cir. 2017) (quoting Johnson v. United States, 559 U.S. 133 (2010)).

62. $924(\mathrm{e})(2)(\mathrm{B})(\mathrm{ii})$.

63. See Johnson v. United States, 135 S. Ct. 2551, 2555-56 (2015).

64. See Starks, 861 F.3d at 315 (citing § 924(e)(2)(B)).

65. Taylor v. United States, 495 U.S. 575, 575 (1990).

66. See id. at 600 .

67. United States v. Taylor, 864 F.2d 625, 626 (8th Cir. 1989), rev'd, Taylor 495 U.S. 575 (1990).

68. Taylor, 864 F.2d at 626.

69. Id. 
On appeal to the Eighth Circuit, Taylor presented only one argument - that second degree burglary was not a "violent felony" within the meaning of the ACCA because "Missouri law distinguishes between burglary in the first degree which involves the potential for violence and burglary in the second degree which does not. ${ }^{" 70}$ The Eighth Circuit, citing its own precedent, ${ }^{71}$ ruled in favor of the government, reasoning that "'burglary' in the sentence enhancement statute means 'burglary' however a state chooses to define it." "72 Taylor's sentence under the ACCA was affirmed, and the Supreme Court later granted certiorari, hearing arguments on February 28, 1990 . $^{73}$

Ultimately, the Supreme Court rejected the Eighth Circuit's interpretation: "Burglary" does not mean "burglary however a state chooses to define it." Because states have varying statutory schemes, the Court feared adoption of the Eighth Circuit's principle "would mean that a person . . . would, or would not, receive a sentence enhancement based on exactly the same conduct, depending on whether the State of his prior conviction happened to call that conduct "burglary." "'75 Instead, the Court concluded that, in order for the sentencing enhancement to apply, a defendant's prior burglary conviction had to comply with the "generic" definition of "burglary."

The Supreme Court turned to the remaining question: What exactly is the "generic" definition of "burglary?"'77 The original version of the ACCA included a definition: "any offense involving entering or remaining surreptitiously within a building that is the property of another with intent to engage in conduct that is a Federal or State offense." ${ }^{.78}$ But when Congress re-codified the ACCA in 1986, the definition of burglary was omitted, ${ }^{79}$ so the Court had to deduce which definition best accomplished the congressional intent of the legislation. ${ }^{80}$

The Court entertained two potential definitions for burglary as a "violent felony"- either the common-law definition or the "generic" definition. ${ }^{81}$ The common-law definition at the core of the "contemporary usage of the term" defines "burglary" as "a breaking and entering of a dwelling at night, with intent to commit a felony." 82 But this definition did not satisfy the Court, as "[t]he

70. $I d$.

71. Id. at 627 (citing United States v. Portwood, 857 F.2d 1221, 1224 (8th Cir. 1988)).

72. Id.

73. See generally Taylor v. United States, 495 U.S. 575 (1990).

74. Id. at 590-91.

75. Id.

76. Id. at 591-96.

77. Id. at 598-99.

78. Armed Career Criminal Act of 1984 Hearing, supra note 46, at 8.

79. Taylor, 495 U.S. at 589-90. "The legislative history as a whole suggests that the deletion of the 1984 definition of burglary may have been an inadvertent casualty of a complex drafting process." Id.

80. Id. at 598 .

81. Id. at 580 .

82. Id. at 592 . 
arcane distinctions embedded in the common-law definition have little relevance to modern law enforcement concerns." ${ }^{83}$ The Court observed that very few state definitions of burglary resemble the definition set forth in common law. ${ }^{84}$ For example, Indiana's definition of burglary does not require that the burglary be committed at night, or even of a dwelling. ${ }^{85}$ Therefore, the Court opted to adopt the generic definition of burglary as the standard: An unlawful or unprivileged entry into, or remaining in, a building or other structure, with intent to commit a crime. ${ }^{86}$ If a state's definition is narrower, or the same as, the generic definition of burglary, then a conviction under that state statute is a "violent felony" under the ACCA, and the mandatory enhanced sentence is warranted. ${ }^{87}$

The Taylor decision relied on legislative history, looking to statements by legislators in hearings on the ACCA. The majority's ringer was the record of statements made by Deputy Assistant Attorney General James Knapp, who testified to the Senate Judiciary Committee that all property crimes were "inherently dangerous" and "excluding such serious felonies against property inadvertently narrows the scope of the Armed Career Criminal Act." ${ }^{88} \mathrm{Mr}$. Knapp's point directly refuted Arthur Taylor's argument that the ACCA only intended to include burglaries that presented a serious potential risk of physical injury; that is, those burglaries that occur when an occupied building is the target. $^{89}$ The majority, agreeing with Mr. Knapp's statement, rejected Taylor's narrow definition because the legislative history supported "burglary" as the "generic sense in which the term is now used in the criminal codes of most states." $" 90$

Justice Scalia was quick to criticize the majority's reliance on legislative history in his concurring opinion, advocating instead that the plain meaning of the offenses enumerated in the ACCA should be applied. ${ }^{91}$ He pointed out that the inquiry into legislative history "does not uncover anything useful." ${ }^{92}$ Justice Scalia suggested that the majority would not have altered their analysis had the legislative history revealed anything to the contrary, but nonetheless agreed that the categorical approach is the appropriate mechanism to determine whether a sentencing enhancement should apply. ${ }^{93}$

As the majority pointed out, the legislative history is unclear regarding the

83. Id. at 593 .

84. See IND. CODE $§ 35-43-2-1$ (2018).

85. Id.

86. Taylor, 495 U.S. at 595.

87. Id. at 599.

88. Id. at 584 (quoting Armed Career Criminal Act Amendments: Hearing on S. 2312 Before the Subcommittee on Criminal Law of the S. Comm. on the Judiciary, 99th Cong., 2d Sess. 14-15 (1986) (statement of Deputy Assistant Att'y Gen. James Knapp)).

89. Taylor, 495 U.S. at 596-97.

90. Id. at 598 .

91. Id. at 603 (Scalia, J., concurring).

92. Id.

93. Id. 
legal process in determining how the definitions of "violent felonies" would be implemented. ${ }^{94}$ But comments from legislators and testifying congressional witnesses on their vision for the ACCA's scope paint a very different picture. ${ }^{95}$ The majority contended that, given the "considerable debate over what kinds of offenses to include and how to define them," particular crime might sometimes count towards enhancement and sometimes not," Congress implicated the categorical approach. ${ }^{97}$

Additionally, the majority favored the categorical approach out of fear that the alternative, facts-based approach to determine whether a state offense constituted a violent felony, potentially violating a defendant's Sixth Amendment right to trial by jury. ${ }^{98}$ The Court posed a question without answering it: "If the sentencing court were to conclude, from its own review of the record, that the defendant actually committed a generic burglary, could the defendant challenge this conclusion as abridging his right to a jury trial?"99 Although the majority insisted that their interpretation of the ACCA was "the only plausible interpretation," 100 the categorical approach exempts dozens of state offenses from the ACCA's sentencing enhancement provision, which in turn, exempts many of the criminals Congress wanted to target, as shown below. ${ }^{101}$

\section{B. The Results of Taylor's Categorical Approach Conflict with Congress's Vision for ACCA}

Lawmakers saw the ACCA as a solution to the crime wave engulfing America in the 1980s, and the congressional record is full of support for federal legislation to "incapacitat[e][] repeat offenders" ${ }^{102}$ and "bring[] prosecutorial resources and more severe penalties to bear on the most serious offenders in a locality." 103 The Taylor decision focused on one of the statutorily enumerated violent felony offenses - burglary. ${ }^{104}$ Although the categorical approach complied with Arthur Taylor's case and charge, the results of applying the categorical approach to the other two definitions alters the scope of the ACCA, conflicting with drafter's vision in two crucial ways. ${ }^{105}$

94. Id. at 587 (majority opinion).

95. Id. at 584-85.

96. Id. at 601 .

97. Id. at $588-89$.

98. Id. at 601 .

99. Id.

100. Id. at 601-02.

101. See generally United States v. Starks, 861 F.3d 306 (1st Cir. 2017); United States v. Doctor, 842 F.3d 306 (4th Cir. 2016); United States v. Peterson, 629 F.3d 432 (4th Cir. 2011).

102. H.R. REP. No. 98-1073, at 2 (1984) (Conf. Rep.).

103. Id. at 5 (quoting Att'y Gen.'s Task Force on Violent Crime, Final Report 30 (1981)).

104. See generally Taylor, 495 U.S. 575.

105. Jonathan Robe, Violently Possessed: Johnson As The Vehicle For Limiting Sentencing 
First, the categorical approach requires federal courts to interpret and apply state criminal law, as circuit and district courts parse out clauses of state statutes to determine whether those statutes comply with the ACCA. ${ }^{106}$ When a defendant has predicate offenses encompassed by the enumerated offenses, as in Taylor, a generic offense of either burglary, arson, extortion, or use of explosives is compared to the elements of the state statute. ${ }^{107}$ But when a defendant has predicate offenses encompassed by the force clause, the categorical approach requires federal courts to interpret dozens of other state statutes - from DUIs ${ }^{108}$ and failure-to-report offenses, ${ }^{109}$ to manslaughter. ${ }^{110}$

This process directly contradicts the concept that one of the original writers of the ACCA, Representative William Hughes, advocated to the House Judiciary Committee. He stated, "[the ACCA] would not put Federal courts in a position of having to interpret and apply State laws." "111 Federal courts reviewing challenges to sentencing enhancements under the ACCA are forced to "interpret and apply State laws" to federal sentencing provisions, ${ }^{112}$ producing discrepancies in sentencing for the same conduct, depending upon the statute of conviction.

A review of circuit court precedent illustrates how the same conduct yields drastically different punishments. Federal prosecutors in the District of Kansas charged David Nicholas with being a felon in possession of a firearm when officers discovered two loaded firearms in his car. ${ }^{13}$ At the time Nicholas was arrested for possession of the firearms, his criminal record contained Montana assault, Kansas armed robbery, and Kansas robbery. The pivotal issue for the trial court and the Tenth Circuit was whether Kansas robbery constituted a "violent felony" as to warrant implementation of the fifteen-year minimum sentence under the ACCA. ${ }^{114}$ Because the physical force element of robbery under the Kansas statute included de minimis physical contact, the court concluded that Nicholas could not be subjected to the ACCA's mandatory minimum sentence. ${ }^{115}$ If Nicholas' criminal record contained a prior conviction for robbery in California, Nicholas would be considered an "armed career criminal" under the ACCA. ${ }^{116}$ But the way Kansas' robbery statute was written spared Nicholas from the fifteen-year hammer. ${ }^{117}$

\footnotetext{
Enhancement Under The Armed Career Criminals Act, 10 Duke J. Const. L. \& Pub. Pol'y SIDEBAR 105, 111 (2015).

106. Id.

107. See United States v. Miller, 246 F. App'x 369, 371-72 (6th Cir. 2007).

108. See Begay v. United States, 553 U.S. 137, 142-44 (2008).

109. See Chambers v. United States, 555 U.S. 122, 124-25 (2009).

110. See United States v. Peterson, 629 F.3d 432, 436-37 (4th Cir. 2011).

111. H.R. REP. No. 98-1073, at 5-6 (1984) (Conf. Rep.).

112. See generally Begay, 553 U.S. 137 (2008).

113. See United States v. Nicholas, 686 F. App'x 570, 571-72 (8th Cir. 2017).

114. $I d$. at 574.

115. Id. at 576-77.

116. See United States v. Chavez-Cuevas, 862 F.3d 729, 739-40 (9th Cir. 2017).

117. See Nicholas, 686 F. App'x at 576.
} 
Federal prosecutors in Maine charged George Bennett with being a felon in possession of a firearm, and sought to attach the sentencing enhancement in his case. ${ }^{118}$ Bennett had two prior convictions for aggravated assault. ${ }^{119}$ Because the Maine statute for aggravated assault included the possible mens rea of "intentionally, knowingly or recklessly," rather than simply "intentionally or knowingly," the First Circuit found that a conviction for aggravated assault in Maine could not be a "violent felony," and Bennett was not an armed career criminal. ${ }^{120}$ If Bennett had assaulted someone under Florida law prior to being convicted of being a felon in possession of a firearm at the federal level, the ACCA's sentencing enhancement would have attached. ${ }^{121}$

The second conflict stems from the categorical approach's exclusion of some of the locations the supporters of the ACCA explicitly wanted to target. ${ }^{122}$ Senator Specter testified to the House Judiciary Committee that the ACCA would have "beneficial impact" in the country's "most heavily burdened jurisdictions . . . [like] Boston, Detroit, Miami, Philadelphia, and Louisville. It is precisely in these kinds of swamped urban centers that this bill is designed to assist." ${ }^{123}$ After Taylor, and after years of the categorical approach dictating which criminals from which states receive the sentencing enhancement, the ACCA no longer applies to many "swamped urban centers." 124

Entire categories of criminals in the cities expressly listed by Senator Specter are exempt from the ACCA's sentence enhancement. Assault and battery with a dangerous weapon in Boston won't qualify as a "violent felony." 125 Third-degree burglary in Ohio does not qualify, ${ }^{126}$ nor does breaking and entering in Michigan. ${ }^{127}$ The Ninth Circuit determined that armed robbery, robbery, and the use of a firearm in commission of a felony in Miami were not "violent felonies" under the ACCA, ${ }^{128}$ even in light of an opposing decision by the Eleventh Circuit. ${ }^{129}$

118. Bennett v. United States, 868 F.3d 1, 2 (1st Cir. 2017).

119. Id. at 3 .

120. Id. at 4,23 .

121. See In re Hires, 825 F.3d 1297, 1301 (11th Cir. 2016).

122. Armed Career Criminal Act: Hearing on H.R. 1627 and S. 52 Before the Subcomm. On Crime of the H. Comm. On the Judiciary, 98th Cong. 25 (1984) (statement of Sen. Arlen Specter, Pennsylvania).

123. Id.

124. Id.; see United States v. Kennedy, 881 F.3d 14, 24 (1st Cir. 2018); see also United States v. Ritchey, 840 F.3d 310, 313 (6th Cir. 2016).

125. Kennedy, 881 F.3d at 19.

126. See United States v. Coleman, 655 F.3d 480 (6th Cir. 2011), abrogated by United States v. Stitt, 860 F.3d 854 (6th Cir. 2017).

127. Ritchey, 840 F.3d at 313.

128. See United States v. Geozos, 870 F.3d 890, 901 (9th Cir. 2017).

129. See In re Robinson, 822 F.3d 1196, 1197 (11th Cir. 2016) (holding that armed robbery qualified as a predicate offense under the ACCA). 


\section{The Taylor Decision's Confusing and Inefficient Progeny}

Not only has the categorical approach limited the ACCA's scope, the decades of precedent furthering Taylor's holding have created a web of case law upholding the categorical approach at the cost of legal clarity. In the conclusion of its Taylor opinion, the Court recognized that some statutes are written in a manner that neither directly complies nor rejects the generic definition of "burglary." That is, some statutes define "burglary" or any other enumerated offense of the ACCA "more broadly" than the generic definitions. ${ }^{130}$ These statutes, the Court stated, require a more in-depth analysis, and leaves the issue unaddressed in anticipation of further litigation on the matter. ${ }^{131}$

In 2005, fifteen years after the Taylor decision, Reginald Shepard appealed his ACCA sentencing enhancement after the First Circuit found that his Massachusetts burglaries were "violent felonies." 132 The Massachusetts burglary statute under which Shepard was convicted was a "nongeneric" burglary definition - it was broader than the definition that the Court provided in Taylor. ${ }^{133}$ Because the Massachusetts statute was a "nongeneric" statute, the categorical approach could not definitively answer the question of whether Shepard had been convicted of "generic burglary." 134 The Court established what would become known as the "modified categorical approach," allowing sentencing courts to examine a very limited set of trial court documents in order to answer the question of whether a defendant had been convicted of the generic version of one of the enumerated offenses. ${ }^{135}$ In the name of the Sixth Amendment right to trial by jury, the Court stipulated that a sentencing court cannot make findings of fact, and limited the sentencing court to making the determination based upon the plea colloquy, charging documents, and jury instructions. ${ }^{136}$

Shepard clearly distinguished between "generic" and "nongeneric" statutes, examining the elements of the state statute to determine if the elements are broader than the "generic" definition of an unlawful or unprivileged entry into, or remaining in, a building or other structure, with intent to commit a crime. ${ }^{137}$ But the Supreme Court did not stop with the Shepard ruling, and issued yet another amendment to the categorical approach in 2016 after Richard Mathis appealed his sentence enhancement. ${ }^{138}$

Mathis appealed his enhanced sentence under the ACCA, arguing that his five Iowa burglary convictions did not qualify as "violent felonies." 139 The convicting

130. Taylor, 495 U.S. at 599-601.

131. Id.

132. Shepard v. United States, 544 U.S. 13, 15-16 (2005).

133. Id. at 17.

134. Id.

135. Id. at 24-26; see Descamps v. United States, 570 U.S. 254, 257 (2013).

136. Shepard, 544 U.S. at 25-26.

137. Id. at 16-20 (citing Taylor v. United States, 495 U.S. 575, 599 (1990)).

138. See generally Mathis v. United States, 136 S. Ct. 2243 (2016).

139. Id. at 2246. 
burglary statute forbade unlawful entry into an occupied structure. ${ }^{140}$ Iowa's definition of "occupied structure" was problematic for the Court, as it included "any building, structure, appurtenances to buildings and structures, land, water or air vehicle, or similar place adapted for overnight accommodation of persons, or occupied by persons for the purpose of carrying on business or other activity therein, or for the storage or safekeeping of anything of value." ${ }^{141}$ Rather than authorize the sentencing court to examine the jury instructions, plea colloquy, and charging documents, as it did in Shepard, the Court rejected the modified categorical approach because the Iowa statute offered "alternative means," rather than "alternative elements." 142

The Court distinguished the Iowa statute in Mathis from the Massachusetts statute in Shepard, asserting that list of possible targets for burglary in the Iowa definition were not elements that the law required the prosecutor to prove, just "alternative means of fulfilling a single locational element." 143 But when comparing the two statutes from Shepard and Mathis, the list of locations seems strikingly similar. The Massachusetts statute at issue in Shepard read: "Whoever, in the night time, breaks and enters a building, ship, vessel or vehicle, with intent to commit a felony." 144 To Justice Kagan and the majority, the alleged distinction was clear. ${ }^{145}$ Justice Alito and the dissenting minority, however, argued that Mathis and Shepard presented the same facts to the Court, and the Court gave two different answers. ${ }^{146}$

Justice Alito attacked the practicality of the Court's test, arguing that the elements-alternative means distinction requires judges to "delve into pointless abstract questions." ${ }^{147} \mathrm{He}$ also asserted, as he did in previous dissents in ACCA cases ${ }^{148}$ that the majority's interpretation unnecessarily complicates Congress's intent for the ACCA, ${ }^{149}$ arguing that "Congress indisputably wanted burglary to count under ACCA; our course has led us to the conclusion that, in many States, no burglary conviction will count; maybe we made a wrong turn at some point." 150

Justice Alito favored practicality, recognizing that Congress intended - though expressed such intention vaguely - that the ACCA include the majority of recidivist criminals engaging in a career of crime. ${ }^{151}$ But the majority

140. IOWA CODE $\S 713.1$ (2017).

141. Id. $\S 702.12$.

142. Mathis, 136 S. Ct. at $2246-48$.

143. Id. at 2246.

144. MASS. GEN. LAws ch. 266, § 16 (2000); see also Shepard v. United States, 544 U.S. 13 (2005).

145. Mathis, 136 S. Ct. at 2249.

146. Id. at 2266-71 (Alito, J., dissenting).

147. Id. at 2268 .

148. See Descamps v. United States, 570 U.S. 254, 281 (2013) (Alito, J., dissenting).

149. Mathis, 136 S. Ct. at 2268-70 (Alito, J., dissenting).

150. Id. at 2268 .

151. Id. at 2267 . 
in Mathis erected another obstacle in the paths of prosecutors on the road to sentencing enhancement under the ACCA by preventing the sentencing court from reviewing any relevant facts to make an accurate determination. ${ }^{152}$ Richard Mathis could have burglarized five homes, or five businesses, conduct clearly within the bounds of generic burglary as the Court defined it. But the Mathis Court argued that did not matter, because Richard Mathis could have potentially been convicted of burglarizing a boat. ${ }^{153}$ To the Court, it is the scope of the conduct encompassed by the state statute that matters, not the conduct of the defendant. ${ }^{154}$ This distinction - a legal fiction crafted by the Court - is radically removed from Congress' vision for the ACCA, and produces unfair discrepancies in sentencing for defendants across the country. ${ }^{155}$

Not only are there discrepancies in which states' statutes qualify a defendant for the sentencing enhancement, there are discrepancies between circuits analyzing the same state statutes. The categorical approach allows entirely different outcomes for the same crime depending on which circuit reviews the conviction. ${ }^{156}$ For example, the Ninth Circuit interpreted Florida armed robbery in a manner opposite the Eleventh Circuit. ${ }^{157}$ A Florida conviction for armed robbery examined by the Eleventh Circuit will carry a fifteen-year sentence under the ACCA. ${ }^{158}$ The same criminal record in the Ninth Circuit would not subject a defendant from the ACCA's sentencing enhancement. ${ }^{159}$

Yet another discrepancy lies within the Eighth Circuit's ruling that armed robbery in Illinois does not count as a "violent felony." 160 The Eighth Circuit's interpretation came after Descamps differentiated between "alternative elements" and "alternative means." " Citing Descamps, the Eighth Circuit determined that the Illinois armed robbery statute did not require the "modified categorical approach," and therefore forbade the sentencing court from examining the Shepard documents at all. ${ }^{162}$ This holding directly conflicts with the Seventh Circuit's 2017 interpretation of the same Illinois statute. ${ }^{163}$ The defendant in the Eighth Circuit case received the fifteen-year mandatory sentence under the ACCA,${ }^{164}$ while the maximum sentence the defendant in the Seventh Circuit case

152. Id. at 2248 (majority opinion).

153. Id. at 2251 .

154. Id.

155. See United States v. Geozos, 870 F.3d 890, 892 (9th Cir. 2017); see also In re Robinson, 822 F.3d 1196, 1197 (11th Cir. 2016).

156. See Geozos, 870 F.3d at 892.

157. See Robinson, 822 F.3d at 1197; see also Geozos, 870 F.3d at 892.

158. See Robinson, 822 F.3d at 1197.

159. See Geozos, 870 F.3d at 892 .

160. See United States v. Bankhead, 746 F.3d 323, 326-27 (8th Cir. 2014).

161. See generally Bankhead, 746 F.3d 323.

162. See id. at 326.

163. See Van Sach v. United States, No. 17-1824, 2017 WL 4842617, at*1 (7th Cir. Sept. 1, 2017).

164. See United States v. Bankhead, 593 F. App'x 602, 603 (8th Cir. 2015). 
could have received was seven years. ${ }^{165}$

Despite the Court's efforts to insulate the ACCA from constitutional challenges with the categorical approach, mainly the Sixth Amendment right to trial by jury, ${ }^{166}$ the Court admitted the ACCA's faults in Johnson v. United States (2015). ${ }^{167}$ The residual clause, the second subsection of $\S 924(\mathrm{e})$ - defining "violent felony" as "involv[ing] conduct that presents serious potential risk of physical injury to another" ${ }^{168}$ — was deemed unconstitutionally vague. ${ }^{169}$ Prior to the ruling, some commentators believed the Court would take the opportunity to strike down the ACCA in its entirety. ${ }^{170}$ Instead, the Court severed the residual clause from the ACCA's definition of "violent felony." ${ }^{171}$ While the Court upheld the constitutionality of the force clause and the enumerated offenses clause, commentators are wary about the implications of the Johnson ruling in future inquiries. ${ }^{172}$ The categorical approach "requires a judge to imagine the idealized ordinary case of the crime," causing vagueness problems to arise. ${ }^{173}$

The Supreme Court's interpretation of the ACCA, and the results it yields, no longer accomplishes the ACCA's intended purpose. The various tests and standards the ACCA requires are not reliable or efficient and often overlap and contradict precedent that interprets the same statutes. The Taylor majority's fears have been realized; the "person convicted of unlawful possession of a firearm" now receives, or does not receive, "a sentence enhancement based on exactly the same conduct, depending on [] the State of [the] prior conviction." "74 The ACCA has been, and still is, subject to constitutional challenges that put it at risk. The solution is simple: The Federal Sentencing Guidelines accomplish what the ACCA was intended to accomplish without the strenuous legal tests and constitutional vulnerability.

165. 720 Ill. Comp. Stat. 5/18-1 (2018).

166. See Taylor v. United States, 495 U.S. 575, 599-601 (1990).

167. See generally Johnson v. United States, 135 S. Ct. 2551 (2015).

168. 18 U.S.C. $\S 924(\mathrm{e})(2)(\mathrm{B})(\mathrm{ii)}$ (2018).

169. See generally Johnson, 135 S. Ct. 2551.

170. Will Baude, Supreme Court Will Consider the Constitutionality of the Armed Career Criminal Act, WASH. Post (Jan. 9, 2015), http://www.washingtonpost.com/news/volokhconspiracy/wp/2015/01/09/supreme-court-will-consider-the-constitutionality-of-the-armed-careercriminal-act [https://perma.cc/J2H6-FVKG].

171. Leah M. Litman, Residual Impact: Resentencing Implications of Johnson's Potential Ruling on ACCA's Constitutionality, 115 Colum. L. ReV. Sidebar 55, 57-59 (2015).

172. Jake Albert, The Flawed Reasoning Behind Johnson v. United States and a Solution: Why a Fact-Based Approach Should Have Been Used to Interpret the Residual Clause of the Armed Career Criminal Act, 25 WM. \& MARY BILl RTS. J. 735, 759 (2016).

173. Id. at 744 .

174. Taylor v. United States, 495 U.S. 575, 590-91 (1990). 


\section{THE GUIDELINES ARE THERE-USE THEM}

\section{A. How the Guidelines Look at Career Offenders}

The Federal Sentencing Guidelines ("the Guidelines"), published annually by the Federal Sentencing Commission ("the Commission"), is a manual to which federal judges refer for a standard when sentencing defendants. ${ }^{175}$ Each offense in the federal criminal code corresponds to a Base Offense Level ("BOL"). ${ }^{176}$ Each conviction on a defendant's criminal record corresponds to a point value, which translates to a Criminal History Category. ${ }^{177}$ The BOL and the Criminal History Category correspond to a specific box on the Guidelines' Sentencing Chart, indicating an advisory sentencing range. ${ }^{178}$

Prior to the establishment of the Guidelines and the Commission, federal sentences did not have the same safeguards and uniform structure that today's sentences do. ${ }^{179}$ Judges and prosecutors had wide discretion with "virtually no appellate review of the sentences imposed." ${ }^{180}$ To address the wide disparities in federal sentences, Congress passed the Sentencing Reform Act of 1984 ("SRA"), the same year that Congress passed the ACCA. ${ }^{181}$

The SRA did not establish the Guidelines, but rather created the Commission as a new arm of the judicial branch. ${ }^{182}$ Using more than 10,000 presentencing reports from across the country, the Commission identified and quantified aggravating and mitigating factors, categorized offenses, demographic and geographic trends; and it predicted "prison impact" - an estimation of growth in prison population based on the new mandatory minimums established by the ACCA. ${ }^{183}$ With all of the data in mind, the Commission produced the first version of the Federal Sentencing Guidelines in $1987 .{ }^{184}$

Like the ACCA, the Guidelines treat recidivist criminals more severely than first-time offenders. ${ }^{185}$ The current version of the Guidelines lays out sections related to "career offenders" and their criminal history in Chapter 4, using the Criminal History Category to establish different levels of recidivism and assign longer prison sentences. ${ }^{186}$ Section B1.1 states:

A defendant is a career offender if (1) the defendant was at least eighteen

175. Sentencing Guidelines, 46 Geo. L.J. AnN. ReV. Crim. Proc. 789, 791-92 (2017).

176. Id. at 793 .

177. Id. at 794-95.

178. Id. at 791-92.

179. Newton \& Sidhu, supra note 29, at 1169.

180. Id.

181. Id. at 1169-70.

182. Id. at $1183-84$.

183. Id. at $1197-99$.

184. Nancy Gertner, A Short History of American Sentencing: Too Little Law, Too Much Law, or Just Right, 100 J. CRIM. L. \& CRIMINOLOGY 691, 698 (2010).

185. U.S. Sentencing Guidelines Manual ch. 4 (U.S. Sentencing Comm'n 2016).

186. Id. 
years old at the time the defendant committed the instant offense of conviction; (2) the instant offense of conviction is a felony that is either a crime of violence or a controlled substance offense; and (3) the defendant has at least two prior felony convictions of either a crime of violence or a controlled substance offense. ${ }^{187}$

This section defines a "crime of violence" differently than the ACCA, explicitly enumerating "murder, voluntary manslaughter, kidnapping, aggravated assault, a forcible sex offense, robbery, arson, extortion, or use or potential use of a firearm or explosive material." 188 This section of the Guidelines reaches beyond the ACCA. The ACCA may be invoked only as a result of a conviction under $\S$ 922(g) - unlawful possession of a firearm-while the career offender classification under the Guidelines may be invoked with a conviction of any federal offense, so long as the defendant's criminal record corresponds to the enumerated offenses in $\S 4 \mathrm{~B} 1.1{ }^{189}$

In addition to referring to the Guidelines' suggested sentencing ranges, federal judges must also consider the seven factors established in 18 U.S.C. § $3553 .{ }^{190}$ The seven factors are:

(1) the nature of the offense and the history and characteristics of the defendant;

(2) the need for the sentence to be imposed [including punishment, deterrence, protect the public] ...;

(3) the kinds of sentences available;

(4) the kinds of sentences and the sentencing range established for [the defendant $]. .$. ;

(5) any pertinent policy statement ...;

(6) the need to avoid unwarranted sentence disparities among defendants with similar records who have been found guilty of similar conduct; and

(7) the need to provide restitution to any victims of the offense. ${ }^{191}$

These factors work in conjunction with the Guidelines, giving sentencing judges the opportunity to make sentencing decisions tailored to each defendant, ${ }^{192}$ whereas the ACCA confines courts to a mandatory minimum fifteen-year sentence, with no option for suspended sentence, and no consideration of mitigating factors..$^{193}$

187. Id. pt. $\mathrm{B}, \S 1.1$.

188. Id. § 1.2(a)(2).

189. Sentencing Guidelines, supra note 175 , at 820.

190. See Kimbrough v. United States, 552 U.S. 85, 100-01 (2007).

191. 18 U.S.C. § 3553(a) (2017).

192. Stephanie Marie Toribio, Note, Effective Criminal Sentencing?: Analyzing the Effectiveness of Federal Sentencing Guidelines on Career Offenders, 22 SuFfOLK J. TRIAL \& APP. ADVOC. 377, 386-88 (2016-17).

193. 18 U.S.C. $\S 924(\mathrm{e})(1)$. 


\section{B. The Guidelines Accomplish What the ACCA Was Designed to Do}

Congress implemented the ACCA to punish individuals who make a career by harming others and their property more severely than they would be punished at the state level, and to deter the "career criminal" from returning to crime after release from prison. ${ }^{194}$ Due to the categorical approach, the ACCA applies only to career criminals whose prior convictions fit what the courts determine to qualify as violent offenses under its definitions. ${ }^{195}$ The Guidelines, on the other hand, consider all prior convictions during sentencing. ${ }^{196}$ The Guidelines encompass all federal criminal defendants, including those convicted by the ACCA.. ${ }^{197}$ The ACCA and the Guidelines are redundant, and the Guidelines are more elegant and more effective than the ACCA's narrow scope. ${ }^{198}$

The Guidelines are preferable to the ACCA because the Guidelines allow judges to make a well-rounded, comprehensive decision on sentencing, while the ACCA simply mandates a sentence based upon a small category of prior convictions. ${ }^{199}$ The Guidelines permit judges to consider how much time passed between convictions, ${ }^{200}$ whether the convictions were "minor" offenses ${ }^{201}$ - such as careless driving, disorderly conduct, gambling, or trespassing - and whether the offenses occurred while serving another prison sentence or while on probation. ${ }^{202}$ Furthermore, if the sentencing judge feels that the Guidelinesrecommended range does not adequately address the nature of the defendant's criminal record, the judge can elect to impose a shorter or lengthier sentence as necessary, on a case-by-case basis. ${ }^{203}$ Such a departure outside of the correctly calculated Guidelines range requires a "sufficiently compelling" reason from the judge for that sentence ${ }^{204}$ and is reviewable on appeal for "unreasonableness."205

Furthermore, the Guidelines are more efficient than the ACCA while addressing the same number of criminals. Unlike the ACCA, the Guidelines do not require courts to delve into an in-depth legal analysis of which prior convictions may be considered in sentencing decisions. ${ }^{206}$ The statutory factors for sentencing in $\S 3553$ authorize judges to consider the entire criminal record, the number of previous offenses as well as the nature of the convictions. ${ }^{207}$

194. H.R. REP. No. 98-1073, at 5 (1984) (Conf. Rep.).

195. $§ 924(\mathrm{e})(2)(\mathrm{B})$.

196. Sentencing Guidelines, supra note 175, at 815-16.

197. U.S. Sentencing Guidelines Manual ch. 4 (U.S. Sentencing Comm’n 2016).

198. Sentencing Guidelines, supra note 175, at 815-17.

199. Id.

200. Id. at 816 .

201. Id. at 820 n.2164.

202. $I d$. at 816 .

203. Id. at $817-18$.

204. Beckles v. United States, 137 S. Ct. 886, 900 (2017).

205. United States v. Booker, 543 U.S. 220, 224 (2005).

206. 18 U.S.C. $§ 3553$ (a) (2018).

207. Id. 
Sentencing courts implementing the Guidelines do not have to entertain arguments on whether a statute is "generic" or "nongeneric," 208 or whether the "nongeneric" statute lists "alternative means" or "alternative elements," 209 as judges sentencing under the ACCA must do.

The ACCA sentencing enhancement can only be invoked with a conviction for unlawful possession of a firearm under 18 U.S.C. $\S 922(\mathrm{~g}) .{ }^{210}$ However, there is an alternative unlawful possession statute: 26 U.S.C. $\S 5861 .^{211}$ This statute, included as part of the Internal Revenue Code, prohibits unlawful receipt, possession, transfer, alteration, or manufacture of firearms. ${ }^{212}$ This section avoids the ACCA sentencing enhancement while punishing the same conduct and allowing the sentencing judge to make a sentencing determination with the Guidelines and $\S 3553 .^{213}$ However, $\S 5861$ only applies to specific types of firearms, mainly shotguns and rifles. ${ }^{214}$ If the firearm at issue is, for example, a handgun, $\S 5861$ is not applicable. ${ }^{215}$ Congress should repeal the ACCA's sentencing enhancement to streamline prosecutions of unlawful possession, producing more equitable sentencing outcomes between $\S 922$ and $\S 5861$, as illustrated below.

\section{Introductory Hypothetical—Revisited}

The hypothetical situation at the beginning of this note presented two men, John and Paul. When both men were charged with unlawful possession of a firearm under $\S 922(\mathrm{~g})$, John received the enhanced sentence under the ACCA because his prior burglary offenses were charged under Indiana law. Paul, on the other hand, did not receive the enhanced sentence because his prior burglary offenses were charged under Illinois law. John and Paul received vastly different sentences because Indiana's burglary statute is "generic"-fitting within the scope of the ACCA's sentencing enhancement-while Illinois' burglary statute is "nongeneric" and too broad to be included under the ACCA's definition. ${ }^{216}$

But if the two men were both charged for unlawful possession under $\S 5861$, the outcome is much more equitable. John and Paul, charged and convicted under $\S 5861$, would be sentenced using the Guidelines and the $\S 3553$ factors, ${ }^{217}$ rather than the ACCA's mandatory minimum, which is dependent on state definitions

208. See generally Taylor v. United States, 495 U.S. 575 (1990).

209. See generally Descamps v. United States, 570 U.S. 254 (2013).

210. 18 U.S.C. $\$ 924(\mathrm{e})(1)(2018)$.

211. 26 U.S.C. $\S 5861$ (2017).

212. Id.

213. See U.S. Sentencing Guidelines Manual ch. 2, pt. K, § 2.1(5) (U.S. Sentencing COMM'N 2016).

214. 26 U.S.C. $§ 5845$ (2019).

215. $I d$.

216. Shepard v. United States, 544 U.S. 13, 25-26 (2005).

217. U.S. Sentencing Guidelines Manual ch. 2, pt. K, § 2.1(5); Sentencing Guidelines, supra note 175 , at 789 . 
of burglary. A conviction under this section carries a Base Offense Level of eighteen under the Guidelines. ${ }^{218}$

For purposes of calculating hypothetical criminal history points, assume that both John and Paul have three prior burglaries in their respective states, serving fifteen months for each of those offenses. Since John's and Paul's sentences for the burglaries exceeded "one year and one month," ${ }^{219}$ they will each receive three criminal history points per offense. ${ }^{220}$ Individuals with nine criminal history points (Category IV) ${ }^{221}$ and a Base Offense Level of eighteen have a suggested range of forty-one to fifty-one months incarceration, approximately three-and-ahalf to four-and-a-half years. ${ }^{222}$

Beyond the standard range, there are several enhancements and departures at prosecutors' and sentencing courts' discretion, allowing them to increase or decrease defendants' sentence on a case-by-case basis. ${ }^{223}$ If the judge felt that Paul's and/or John's criminal record warranted a lengthier sentence, the judge could hand down a lengthier sentence so long as he or she provided reasoning for the departure from the upper limit of the Guidelines' range. ${ }^{224}$

As the law stands today, this hypothetical is not possible because $\S 5861$ can only be charged for a few types of weapons. ${ }^{225}$ Handguns and some rifles are not included in $\S 5861$ and can only be charged under the ACCA's sentencing enhancement in $\S 922 .{ }^{226}$ If the ACCA sentencing enhancement were repealed, judges would have a wide array of sentencing options for all weapons offenses to better fulfill the vision the original Sentencing Commission presented with the Guidelines. ${ }^{227}$ As Justice Breyer-who served on the original Sentencing Committee - pointed out in a speech at the University of Nebraska College of Law, mandatory minimums are not helpful, and they take away necessary flexibility in sentencing. ${ }^{228}$ Breyer also stated, "[1]ike law itself, the guidelines sought a better balance between rules that promote uniformity among cases and practices that focus upon fairness and equity in the individual case."229

But this comparison also illustrates why some commentators and policymakers defend the ACCA as a useful tool in plea negotiations: A mandatory

218. U.S. Sentencing Guidelines Manual ch. 2, pt. K, § 2.1(5).

219. Id. at ch. 4, pt. A, § 1.1(a).

220. Id. at ch. 5 , pt. A.

221. Id.

222. $I d$.

223. Id. at pt. K, $\S 2.0$ (a).

224. Sentencing Guidelines, supra note 175 , at 816-17.

225. 26 U.S.C. $\S 5845$ (2018).

226. Id.

227. Sentencing Guidelines, supra note 175, at 789.

228. Brian Carlson, Justice Says Mandatory Minimum Sentences Are Restrictive, DAILY NEBRASKAN (June 15, 2006), http://www.dailynebraskan.com/justice-says-mandatory-minimumsentences-are-restrictive/article_9a4fc975-a3d3-5d23-9a9a-4618c3dc5af2.html [https://perma.cc/C5RP-BLFP].

229. Id. 
fifteen-year sentence for conduct that, under the Guidelines, would normally warrant a sentence of three-and-a-half to four-and-a-half years gives federal prosecutors leverage. ${ }^{230}$ The threat of an automatic fifteen-year prison sentence can be held over a defendant's head in an effort to get them plead guilty to certain charges in exchange for others to be dropped, or entice cooperation in investigation or prosecution of another crime. ${ }^{231}$ But a useful plea negotiation tool is hardly worth a contradictory web of case law in the circuit courts and substantial sentencing disparities while many of the criminals that Congress intended to target with the ACCA elude the mandatory minimum meant to keep them off the streets. ${ }^{232}$ While the fifteen-year sentence would no longer be automatic, the sentencing judge could certainly hand down a fifteen-year sentence using the sentencing factors set forth in 18 U.S.C. $§ 3553 .{ }^{233}$

\section{CONCLUSION}

In 1984, Congress committed itself to solving the crime crisis in America, and the ACCA was part of that effort to create a more aggressive federal criminal system. In 1990, the Supreme Court decided in Taylor v. United States that the categorical approach was the only constitutional option in interpreting and applying the ACCA's sentencing enhancement provision to predicate state offenses. While the Court ruled the sentencing enhancement applied to the defendant in Taylor, the application of the categorical approach has resulted in defendants across the country being exempted from the ACCA's reach, thereby contradicting Congress's vision.

Twenty-seven years after Taylor, court opinions and legal commentary on the ACCA are complex, impractical, and at times, contradictory. Courts have limited the scope of the ACCA's sentencing enhancement, with its application depending on how the jurisdiction of the ACCA conviction analyzes the statute of the jurisdiction of the previous convictions. Even conceding that the categorical approach was the only option in interpreting the ACCA, the resulting discrepancies now demand reconsideration of the ACCA's merit.

In the midst of such reconsideration, one must realize why the 1984 Congress drafted and passed the ACCA in the first place: To curb the crime wave by punishing criminals with longer criminal histories more severely, keeping them off the streets for longer periods of time. The Guidelines further that intent more than the now-watered-down ACCA does. The Guidelines look at a defendant's criminal history with a wide lens, while the ACCA is constrained by a formalistic analysis and a web of state statutes. The Guidelines offer a ready replacement should the ACCA be repealed, with widespread applicability and flexibility across all offenses - regardless of the convicting jurisdiction.

230. Steven R. Sady, The Armed Career Criminal Act-What's Wrong with Three Strikes, You're Out?, 7 FED. SENT'G REP. 2, 69-70 (1994).

231. Id.

232. United States v. Starks, 861 F.3d 306, 310 (1st Cir. 2017).

233. 18 U.S.C. $\S 3553$ (2018). 
Repealing the ACCA and amending the definition of "firearm" in $\S 5861$ to include handguns would streamline federal sentencing and produce more equitable results. It's time for Congress to follow-up on the landmark legislation that helped curb the crime wave. Congress created and funded the emboldened federal criminal justice system of today, and Congress is responsible to the inequities that system produces. Similar conduct and similar criminal histories deserve similar sentences, and repealing the ACCA and replacing it with an amended $\S 5861$ would be a step toward accomplishing that goal. 